\title{
An Approach to the Paradigms of Public Administration in Ecuador, from a Purely Bibliometric Study
}

\author{
Nancy del Rocio Flores Hinojosa, Alexander Báez Hernández \\ Administrative Sciences Department, Central University of Ecuador, Quito, Ecuador \\ Email:nrflores@uce.edu.ec, albaez@uce.edu.ec
}

How to cite this paper: del Rocio Flores Hinojosa, N., \& Hernández, A. B. (2022). An Approach to the Paradigms of Public Administration in Ecuador, from a Purely Bibliometric Study. Open Journal of Social Sciences, 10, 84-99.

https://doi.org/10.4236/jss.2022.101007

Received: November 11, 2021

Accepted: January 10, 2022

Published: January 13, 2022

Copyright $\odot 2022$ by author(s) and Scientific Research Publishing Inc. This work is licensed under the Creative Commons Attribution International License (CC BY 4.0).

http://creativecommons.org/licenses/by/4.0/

\begin{abstract}
Describing the situation of the Ecuadorian Public Administration, like that of any other country, is obviously not an easy task. In the first place, due to the absence of research in this field and secondly because its problems can never be fully quantified, especially because each of them, in turn, contains a number of other problems or sub-problems, weaving a true network of interrelationships to even shape what could be classified as a system of problems. The purpose of this scientific contribution is to show the bibliometric performance of the Public Administration paradigms. To achieve this purpose, an exhaustive bibliographic review of the literature and published articles related to this topic is carried out in the academic and research database Scopus. The results of this work expose the following points: 1) Paradigms of public administration, a strictly bibliometric analysis; 2) The public administration in Ecuador; 3) Social reality of the Ecuadorian context; 4) Reality of Public Administration at the National Level in Ecuador. The main conclusions highlight that: 1) If a comparison is made between the past and the present, public administration was not conceived as a science, much less talked about the public, the states work daily depending on the urgent activities that were necessary to execute them, unaware that this theory is the foundation for the application of an order within the organization; 2) It can be established that the study of public administration is a very broad and dynamic fact to understand, not only because it is analyzed from the point of view of the social sciences, where the purpose is the fulfillment of collective needs, as well as also the study of the norms that must be applied for the correct development of the state apparatus studied as an activity.
\end{abstract}

\section{Keywords}

Political Science, State Management, People's Power, Public Administration, 
Text Mining, Bibliometrics

\section{Introduction}

The public administration is a system of imprecise limits that includes the set of communications with the public government of the city and looks for the public organizations that carry out the administrative and management function of the State and other public entities with legal personality, whether of regional or local (Kisil, 1982).

In strictly academic terms, the public Administration is in charge of putting citizens in direct contact with the political power through the figure of public servants "satisfying" the collective interests immediately, in contrast to the legislative and judicial powers that do so. They do it in a mediate way (Oliart, 1958). Given the way in which Public Administration is related to citizens and the governmental dynamics to which it is subject, it is, then, a branch of Political Science; That is why Public Administration is, traditionally, studied within said social science in a complementary way (Henry, 1975).

It is mainly regulated by the executive branch and the organizations that are in permanent contact with it. As an exception, some units of the legislative power integrate the notion of "Public Administration", such as state companies, while there may be games of "General Administration" in the other four powers or in state agencies that may depend on one (Basheka, 2012).

The administration comprises the set of communications with the public government of the city, the way in which the public administration relates to citizens and the governmental dynamics to which it is subject to change (Salarzehi \& Ebrahimpour, 2012).

The notion reaches out to teachers and other public education workers, as well as to professionals in state health centers, the police, the military, the national park service, and the postal service (White, 1964). In a broader concept, public administration can be considered any sector or entity that generates or receives its resources from some source of state financing (Oszlak, 1999). On the other hand, it is debated whether it is made up of public services provided by private organizations licensed by the State (Ossorio, 2007). The concept does not reach the state entities that perform the legislative function or the judicial function of the State (Lovrich Jr, 1985).

Public Administration is the discipline that is in charge of efficient, responsible and equitable public management (Valle Franco, 2020: p. 128). One of the main objectives of this career is to address the problems of citizenship and civil society in general (Bapuji, 1989; Desmarchelier, Djellal, \& Gallouj, 2019).

The purpose that the State intends through the administration: is to achieve "the common good" or "general welfare" of the entire population in general. The Public Administration has the duty to offer the provision of its services to citizens with maximum effectiveness and efficiency (Henry, 2015; Lovrich Jr, 1985). 
In the constitutional provisions of Ecuador, article 227 establishes the following: Art. 227.-Public administration constitutes a service to the community that is governed by the principles of effectiveness, efficiency, quality, hierarchy, deconcentration, decentralization, coordination, participation, planning, transparency and evaluation.

Estrada (2011) in his publication "Public Management and Quality: towards continuous improvement and redesign of public sector institutions" states that: "Indeed, in a detailed analysis, the first thing to consider is that the new management represents a transcendental change from the traditional perspective of Public Administration, to a system that emphasizes results, that demands greater responsibility and institutional flexibility and that this change, not without controversy, forces us to assume a position regarding the future of the public sector, for which there is no doubt that this change will inevitably be managerial; both in theory and in practice."

In the case of Ecuador directly or indirectly, these guidelines are followed and significant progress has been made, which is evidenced in its labor and social legislation that has benefited the public sector. So much so that since the presidency of Juan José Flores, the beginning of the republican life of Ecuador, he deals with politics, territorial security and tax collection. On his side, Gabriel Garcia Moreno (1860-1875) centralized state power. During the Liberal Revolution, the State expanded the field of influence of the public sector through the creation of the Ministries of the Interior and Finance.

The Juliana Revolution, established reforms to the restructuring of the State, in 1923, at the same time that it created the Pension Fund, to give social protection, especially to public employees.

In 1927 the Central Bank of Ecuador and the Superintendency of Banks were created, with the advice of the Kemmerer Mission, with the purpose of regulating and controlling the national financial system, with which a new structure for the administration of the State was experienced.

In 1928 the Organic Law of Finance was promulgated, which regulates appointments, salaries, responsibilities, etc. of public servants.

In 1959, the Administrative Career Law was issued in order to provide stability to public employees, train them technically, and a selection system began to occupy public positions.

In 1968, the Civil Service and Administrative Career Law established: a personnel administration system, based on merit; equal opportunities, without discrimination for Ecuadorians; and the formation of a career in public administration.

Forty years ago, the military dictatorship that coincided with oil exports assumed control of the State, increased the bureaucracy by creating a series of public companies of basic services, the military supply, for oil and mineral exploitation. There is also a regional decentralization and deconcentration of the State. 
In the Presidency of Jaime Roldós, 1980-1984, a National Development Plan is initiated, the Government assumes the direction of social policy, in health, social, housing, education and environmental sanitation services.

In 1989, under the presidency of Rodrigo Borja, the National Secretariat for Administrative Development was created, which would be in charge of modernizing the Ecuadorian public apparatus; in this decade there was an increase in the size of the public sector.

In 1992, in the government of Sixto Durán Ballén, given the excessive growth of public servants, he created the National Council for the Modernization of the State, which significantly reduced the number of public servants.

In October 2010, the Government of Rafael Correa, the Organic Law of the Public Service was enacted, setting policies and practices to which the Public Sector must adhere, accentuating the centralization of the State.

Currently, in the different public sector organizations there are around 500,000 employees, of which the majority are professionals with higher level training, who exercise directive, supervisory and planning functions. It should also be noted that in this Government the number of state portfolios and specialized offices have been considerably increased in order to incorporate all areas of public administration under state tutelage and control (Terán, 2018; Zamora-Boza, Arrobo-Cedeño, \& Cornejo-Marcos, 2018).

From what has been described, the evolution of the Public Administration in Ecuador, the State is the body that gives the guidelines of the organizational culture in public institutions, establishing as a principle that public service and administrative career is to promote professional development, technical and staff of public servants, to achieve permanent improvement, efficiency and effectiveness, quality, productivity of the State and its institutions, this means that unlike the private sector, public institutions must be accountable to citizens (Terán, 2018).

The objective behind this document is to show the bibliometric performance of the paradigms of public administration. To achieve this purpose, an exhaustive bibliographic review of the literature and published articles related to this topic is carried out. This document is composed of the following sections: 1) Paradigms of public administration, a strictly bibliometric analysis; 2) The public administration in Ecuador; 3) Social reality of the Ecuadorian context; 4) Reality of Public Administration at the National Level in Ecuador. This research concludes that: If we make a comparison between the past and the present, the public administration was not conceived as a science, much less talked about the public, the states work daily depending on the urgent activities that were necessary to execute them, not knowing that this theory is the foundation for the application of an order within the organization.

\section{Materials and Methods}

This article is based on bibliographic research on the approach of the paradigms 
of public administration. This contribution uses the tools offered by the Scopus directory. Since this directory represents many of the journals with the greatest impact and visibility that project the results in research and advances in this subject of political science. In addition, the bibliometric mapping and analysis tool VOSviewer is used. This software was used to:

1) Create maps based on network data.

2) View and explore maps.

The data extracted from the Scopus academic directory were exported as CSV files, to be processed in the aforementioned bibliometric analysis tool (Alonso, Perez, \& Hidalgo, 2016; Bravo Hidalgo \& León González, 2018). The exploration analyzes works from 2000 to 2021, under the search criteria, "paradigms of public administration", which was applied to the title, abstract and keywords of the contributions. The search showed a total of 1015 documents such as scientific articles, conference records, books and legislation, in the previously declared period. From these, the contributions with the highest Hirsch index (H Index) were selected, and which specifically referred to the south-themes such as: Political Science, State Management, People's Power, Public Administration, Text Mining, Bibliometrics.

\section{Results and Discussion}

\subsection{Paradigms of Public Administration, a Strictly Bibliometric Analysis}

The study of Public Administration is one of the research areas of political science. Political science is the study and analysis of political and governmental processes. It includes the study of different government systems, electoral processes, political parties, political ideology, historical analysis, political theory, changes in power and much more. In this context and on a global scale, in recent years there has been a gradual increase in the number of investigations and as a consequence of publications related to this topic. Under the search criteria declared in the Materials and methods section, and using the bibliometric tools offered by the Scopus academic platform, the graph shown in Figure 1 was made. This figure shows the quantitative evolution of research in this area of knowledge, in the last 20 years. In the aforementioned figure, it can be seen that there is a growing trend in the number of published scientific contributions, mainly from 2012. This fact is one more element, which supports the justification of this review-type article.

Using the bibliometric analysis tool of scientific activity and production VOSviewer, text mining is performed on the title, abstract and keywords of the detected publications. This process produced the graph shown in Figure 2. This figure shows a map of terms with the highest co-occurrence in research related to the topic Paradigms of Public Administration. This figure offers a clearly visual panorama (The yellow areas without the most recurrent terms and the blue areas those with the least recurrence). 


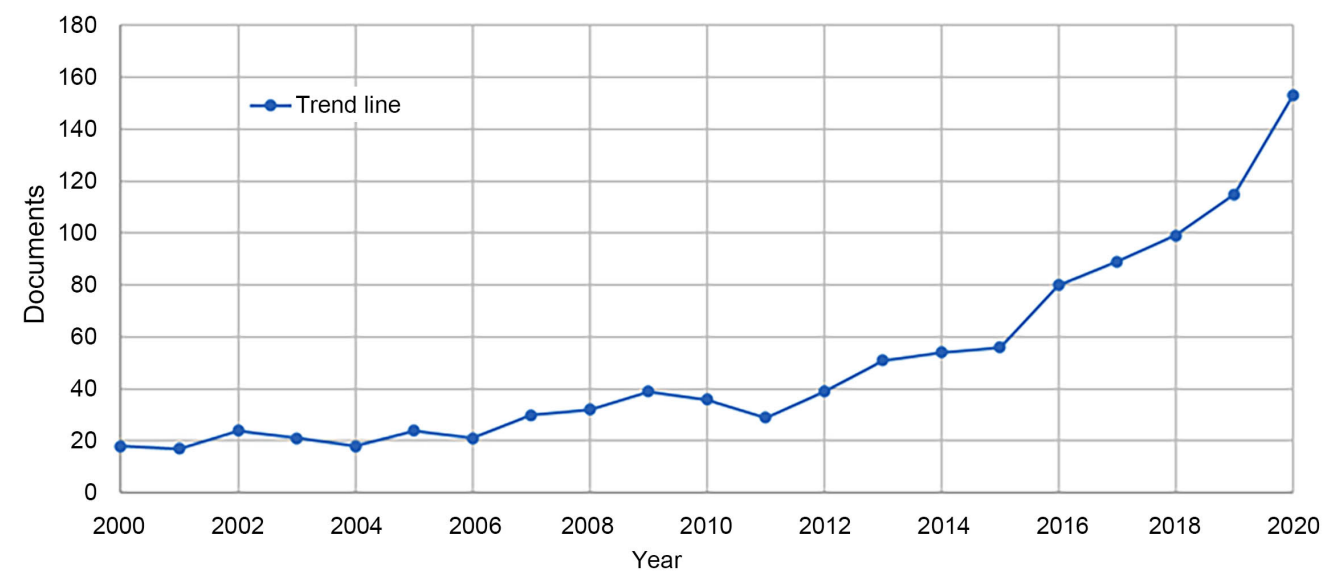

Figure 1. Evolution of scientific activity, measured in publications registered per year, in the period 2000 to 2020 .

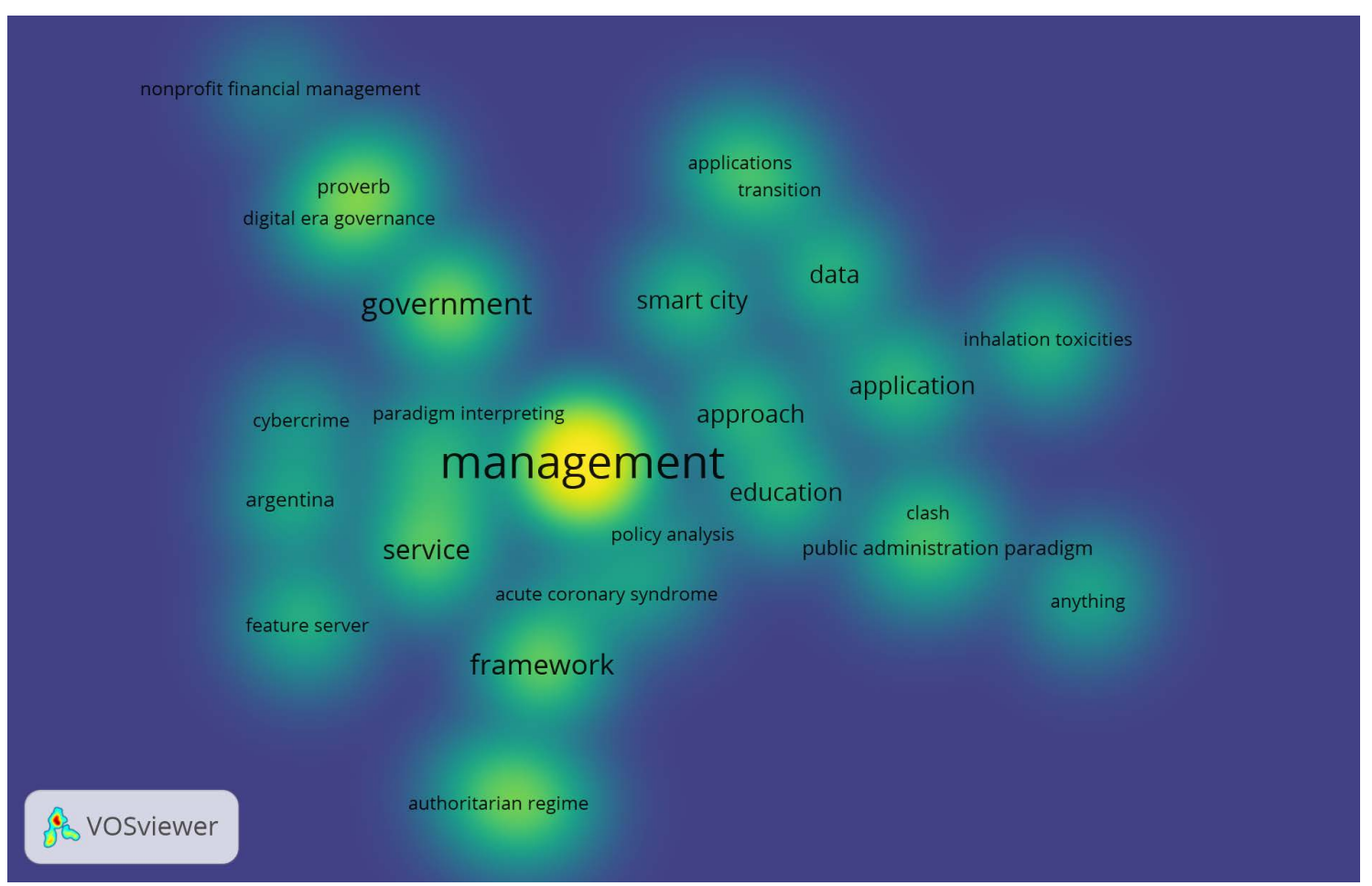

Figure 2. Map of terms of the text mining process on the title, abstract and keywords of the investigations detected. Only terms with a co-occurrence factor equal to or greater than 5 are considered.

The research published in relation to the paradigms of Public Administration has had a boom in recent years, as has already been demonstrated. The authors of these contributions are distributed by the most diverse nations around the globe. They are related to collaborate on your publications, at various levels and in various ways. Figure 3 shows the interaction network of the most productive researchers on an international scale on the subject of Paradigms of Public Administration. This collaboration network by author is represented in different colors that highlight the most frequent clusters or groups of collaborating researchers. 


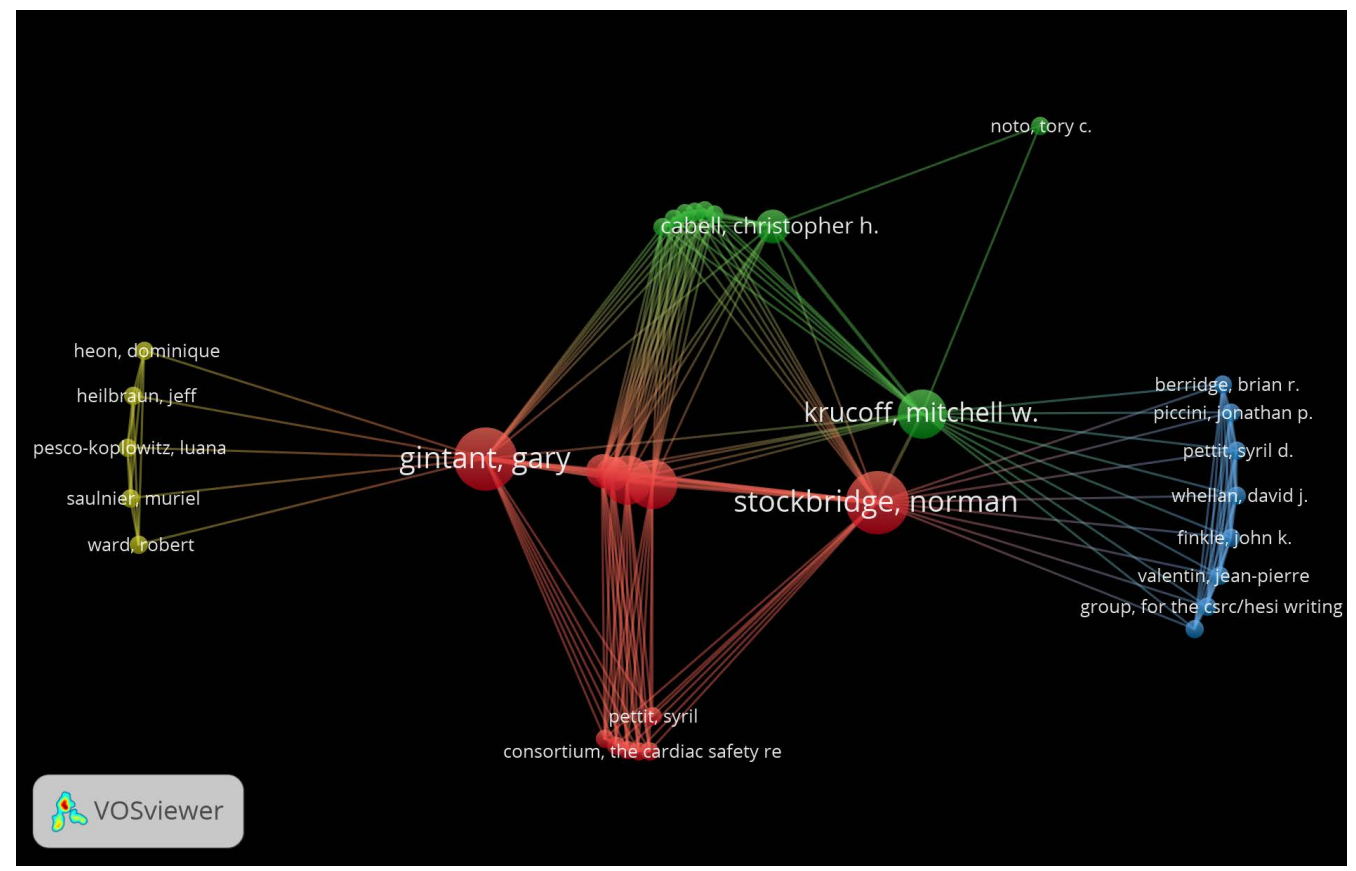

Figure 3. Network of relationship and collaboration of the most prolific authors in published studies in relation to the paradigms of public administration. Only authors with an $\mathrm{h}$ index equal to or greater than 4 . The $\mathrm{h}$ index is considered the $\mathrm{h}$ index is an author-level metric that measures both the productivity and the impact of the citations of the publications, initially used for a scientist or academic individual. Proposed by Jorge Hirsch, from the University of California, 1 measures the professional quality of scientists, based on the number of citations their scientific articles have received. A scientist or researcher has an $\mathrm{h}$ index if he has published $\mathrm{h}$ papers with at least $\mathrm{h}$ citations each.

The nations with the largest publications on this subject are the United States of America, Germany, China, India and France. The scientific journals that offer the greatest projection to this subject are the following ordered from highest to lowest:

- International Journal of Public Administration;

- Administration \& Society;

- Public Policy and Administration;

- Public Administration Review.

Table 1 shows the objective, scope, methods and main results of the most cited scientific publications in recent years, related to Public Administration. The table is ordered from highest to lowest according to the number of citations received up to the date of this document. This table offers a qualitative vision of the world-wide Public Administration research environment.

\subsection{The Public Administration in Ecuador}

The public administration is conduction; it is a manifestation of the government of the interests and/or goods, especially of the public ones. Management science is the set of rules for managing businesses and institutions; and more particularly to employ the means and resources in obtaining the ends of a state, company, etc. In other words, science, matter, the object that deals with plus and minus, 
Table 1. Most cited publications in the studies of paradigms of public administration, on a global scale.

\begin{tabular}{|c|c|c|c|c|}
\hline Title & Authors & Abstract & Citations & References \\
\hline $\begin{array}{l}\text { The "new public } \\
\text { management" } \\
1 \text { in the 1980s: } \\
\text { Variations on a } \\
\text { theme }\end{array}$ & $\begin{array}{l}\text { Christopher } \\
\text { Hood }\end{array}$ & $\begin{array}{l}\text { Changes in public sector accounting in a number of OECD countries } \\
\text { over the 1980s were central to the rise of the "New Public } \\
\text { Management" (NPM) and its associated doctrines of public } \\
\text { accountability and organizational best practice. This paper discusses } \\
\text { the rise of NPM as an alternative to the tradition of public } \\
\text { accountability embodied in progressive-era public administration } \\
\text { ideas. It argues that, in spite of allegations of internationalization } \\
\text { and the adoption of a new global paradigm in public management, } \\
\text { there was considerable variation in the extent to which different } \\
\text { OECD countries adopted NPM over the 1980s. It further argues that } \\
\text { conventional explanations of the rise of NPM ("Englishness", party } \\
\text { political incumbency, economic performance record and } \\
\text { government size) seem hard to sustain even from a relatively brief } \\
\text { inspection of such cross-national data as are available, and that an } \\
\text { explanation based on initial endowment may give us a different } \\
\text { perspective on those changes. }\end{array}$ & 2200 & (Hood, 1995) \\
\hline $2 \begin{array}{l}\text { Public Value } \\
\text { Management }\end{array}$ & Gerry Stoker & $\begin{array}{l}\text { The aim of this article is to clarify the nature of the management } \\
\text { style most suited to the emergence of networked governance. The } \\
\text { paradigms of traditional public administration and new public } \\
\text { management sit uncomfortably with networked governance. In } \\
\text { contrast, it is argued the public value management paradigm bases } \\
\text { its practice in the systems of dialogue and exchange that characterize } \\
\text { networked governance. Ultimately, the strength of public value } \\
\text { management is seen to rest on its ability to point to a motivational } \\
\text { force that does not solely rely on rules or incentives to drive public } \\
\text { service practice and reform. People are, it suggests, motivated by } \\
\text { their involvement in networks and partnerships, that is, their } \\
\text { relationships with others formed in the context of mutual respect } \\
\text { and shared learning. Building successful relationships is the key to } \\
\text { networked governance and the core objective of the management } \\
\text { needed to support it. }\end{array}$ & 656 & $\begin{array}{l}\text { (Stoker, } \\
2006)\end{array}$ \\
\hline $\begin{array}{l}\text { The Dynamics of } \\
3 \text { Political Control } \\
\text { of the Bureaucracy }\end{array}$ & $\begin{array}{l}\text { B. Dan Wood, } \\
\text { Richard W. } \\
\text { y Waterman }\end{array}$ & $\begin{array}{l}\text { A new paradigm of political-bureaucratic relations emerged through } \\
\text { the 1980s holding that U.S. democratic institutions continuously } \\
\text { shape nonelective public bureaucracies. Several empirical studies } \\
\text { support the paradigm with evidence suggestive of political } \\
\text { manipulation but none reveals the scope or specific mechanisms of } \\
\text { political control. We explore the dynamics of political control of the } \\
\text { bureaucracy explicitly to determine the scope and mechanisms. We } \\
\text { examine output time series from seven different public bureaucracies } \\
\text { for responsiveness to political tools applied in the late Carter and } \\
\text { early Reagan administrations. We find responsiveness in all seven } \\
\text { cases. The evidence also shows that political appointments-a shared } \\
\text { power of the president and Congress-is the most important } \\
\text { instrument of political control; changing budgets, legislation, } \\
\text { congressional signals, and administrative reorganizations are less } \\
\text { important. These findings confirm intuitive assertions by } \\
\text { institutional scholars and suggest a method of "policy monitoring" } \\
\text { that could enhance future democratic control of the bureaucracy. }\end{array}$ & s 373 & $\begin{array}{l}\text { (Wood \& } \\
\text { Waterman, } \\
\text { 1991) }\end{array}$ \\
\hline
\end{tabular}


A raft of new research on the causes and effects of political corruption has emerged in recent years, in tandem with a separate, growing focus on the effects of political institutions on important outcomes such as economic growth, social equality and political stability. Yet we know little about the possible role of different political institutional arrangements on political corruption. This article examines the impact of territorial sovereignty (unitary or federal) and the composition of the executive (parliamentary or

Political

Institutions and

4 Corruption: The Strom C. and Role of Unitarism Thacker

Parliamentarism presidential) on levels of perceived political corruption cross-nationally. We find that unitary and parliamentary forms of 240 government help reduce levels of corruption. To explain this result,

(Gerring \& Thacker, 2004) we explore a series of seven potential causal mechanisms that emerge out of the competing centralist and decentralist theoretical paradigms: 1) openness, transparency and information costs, 2) intergovernmental competition, 3) localism, 4) party competition, 5) decision rules, 6) collective action problems, and 7) public administration. Our empirical findings and our analysis of causal mechanisms suggest that centralized constitutions help foster lower levels of political corruption.

Community health workers (CHWs) have gained increased visibility in the United States. We discuss how to strengthen the roles of CHWs to enable them to become collaborative leaders in

Hector Community healthBalcazar, E Lee dramatically changing health care from "sickness care" systems to
workers can be a Rosenthal, J systems that provide comprehensive care for individuals and families workers can be a Rosenthal, J public health force Nell and supports community and tribal wellness.

5 for change in the Brownstein, We recommend drawing on the full spectrum of CHWs' roles so that146 United States: Carl H Rush, they can make optimal contributions to health systems and the three actions for a Sergio Matos, building of community capacity for health and wellness. new paradigm. Lorenza Hernandez

We also urge that CHWs be integrated into" community health teams" as part of "medical homes" and that evaluation frameworks be improved to better measure community wellness and systems change.

In the context of shared services implementation within the Portuguese public administration a new initiative named Governmental Open Cloud (GO-Cloud) has emerged. The GO-Cloud initiative implementation overlays the double objective of establishing a technological platform that will leverage the shared services adoption spreading among public administration entities, concerning both the already deployed financial and budgetary
The Portuguese government cloud $6 \begin{aligned} & \text { services, } \\ & \text { deployment and }\end{aligned}$ management framework
José Gomes, management solution and the shared human resource management Luisa Domingues solution, and the provisioning of ICT resources and services in a
(Balcazar et al., 2011)

(Gomes \& Domingues, 2014)
The Portuguese shared services solution is based on a service-oriented architecture which facilitates the adoption and integration of the cloud computing paradigm and the relating short term expected economical and structural benefits concerning both governmental efficiency and effectiveness. Two of the major risks concerning GO-Cloud are the relative lack of maturity of cloud computing technology and standards as well as the cultural and 
organizational change it introduces within public administration universe of more than 510,000 employees. In order to properly deal with these threats two initiatives have been taken: 1) at the technical level to build an open cloud based on existing technologies and interconnection standards; 2) at the management level to develop a governance model able to address and support its implementation, development and management.

This paper focuses in both aspects: the GO-Cloud services architecture and its respective deployment and governance models. The deployment model is inspired in the web services paradigm and the management model deploys the Shared Services Analysis Model (SSAM) to the cloud in a three-layer management approach (strategy, business and operation).

that is, order, discipline; one is more and the other is less; Some dispose, others obey and do things. This is the fundamental principle that Adam Smith established in the late 18th century; who divided the work into two categories: supervision or planning and operational or execution (Smith, 1776). Administrative rules; They consist of all those principles, norms, regulations and laws; that provides the adequate legal framework for what is management, conduction; that is, the administration of a public or private body (Ricoy, 2005).

The public administration, consequently, is the administrative system of a state, of a city, of a commune or population center; and its existence is based on two essential reasons: Provide public services to the community to whom it is owed; and exercise public controls over people and property within its domain. With these objectives, the norms and laws that regulate the public administration must: Establish the appropriate administrative agencies; granting them certain powers, describing their scope and limits. Provide the means to enforce administrative decisions made in the exercise of these powers; and provide them with a system that provides security against arbitrary, discriminatory or unauthorized administrative actions. The administrative powers or authorities established by modern standards are of four types:

- The Normative: power that has the capacity to generate general norms or regulations.

- The Patent: power that can grant the use, renewal and revoke licenses or permits to carry out activities.

- The Investigative: power obtained by the testimony to produce information and data to produce an effective regulation.

- The Executive: power that issues administrative orders to be executed by the community.

Ecuador, in more than a century and a half of turbulent history, has achieved material and cultural progress of relative importance, which has been evidenced in social legislation for the public sector. Here is a brief historical synopsis in chronological order:

- In 1923 the Pension Fund was created, to provide social protection in partic- 
ular to public employees. In 1928 the Organic Law of Finance was promulgated to regulate their appointments, salaries, responsibility, etc. of public servants.

- In 1959, the Administrative Career Law was published that establishes: the stability of public officials; your technical training; and its selection system.

- In 1968, the Civil Service and Administrative Career Law established: a personnel administration system, based on merit; equal opportunity, without discrimination for all Ecuadorians; and a career in public administration.

Later this Law has been reformed by means of other laws and decrees; coming to these days in the 90s; when the State begins an integral process of transformation with its modernization.

Currently in the different public agencies of the state there are about 500,000 public employees, of which the majority are professionals of higher level, who exercise directive, supervisory and planning functions. A modern state cannot exist if it does not have a modern public administration. This Modern Administration, on the other hand, cannot exist if it is not led by highly trained and updated public officials in the two basic functions of a State: providing services and exercising control of people and property (Jianu, Ciobanu, \& Cioboata, 2013).

\subsection{Social Reality of the Ecuadorian Context}

To understand the administrative phenomenon, it is essential to place it in the context of the social reality within which it unfolds. The current one is a reality characterized by vertiginous advances and transformations especially in the field of technology and scientific development, but at the same time by a very high degree of obsolescence, not only in technological and material aspects, but even in those that traditionally they constitute the very essence of the value systems that sheltered the action and behavior of individuals, peoples and their organizations. Thus, for example, while in past times social justice was considered irrelevant and even subversive to any effort to correct deep inequalities, today it is conceived not only as an essential value, but also as a strategic one for the development of humanity and, still, as a right that, at the level of aspiration, does not even require the fulfillment of a duty as a counterpart (Basheka, 2012; Henry, 1975).

It is also colored by an environment that is increasingly complex and turbulent, and as such to a high degree unknown and uncertain, especially given the interdependence of people, societies and countries. The unlikely increase in uncertainty that threatens any attempt at security; the force of social circumstances, the new forms of demands that express needs, and, finally, all these explosions that, according to the contribution of Guevara Carrillo (2006), daily force man to change his own ideas, about of its role in organizations, and in society, as their continent. Moreover, they have forced him to learn to live with a new form of nostalgia, which until recently was not fully known, and which today, regardless of age, sex, and status, but in different ways, is part of the general state. of hu- 
manity: depression, as the most obvious expression of the existential anguish of man at the end of the century.

In short, it is a social reality in crisis. Today the crisis is a luxury available to everyone. You too can enjoy it, whatever your age, sex, condition or job. While for some analysts the problem encompasses the universality of the Capitalist System, for others it includes the different social systems and practically two essential aspects of contemporary organizations. The interpretation in any case is tragic: We are facing a comprehensive crisis, whose roots are found in human behavior, in the negative practice of current values or in their transposition and, ultimately, in the distortion, conscious or not, induced or not, deliberate or not, of social intelligence.

This is the reality of a society, a mixture of perplexity and nonconformity, incomprehensible developments and unspeakable miseries, a society in which the instantaneous surpasses all rhythm. In other words, food is instantaneous, education is instantaneous, even cities are instantaneous, and even celebrity is instantaneous-no socio-economic product like this is manufactured faster, or destroyed more ruthlessly.

All this constitutes, in short, the challenge of today's world and forces us to reflect on those strategies that make it possible for us to face the great scarcity, the changes and their speed and, even more, the immediacy of those changes that, together, they condition and will do more in the future our capacity to respond as individuals, as organizations, as peoples, as States and in short as humanity. It is within this context that this product of society, which is the Administration, develops and therefore, it is from this platform that we should envision its future.

\subsection{Reality of Public Administration at the National Level in Ecuador}

Describing the situation of the Ecuadorian Public Administration, like that of any other country, is obviously not an easy task. In the first place, due to the lack of research in this field and secondly because its problems can never be fully quantified, especially because each of them, in turn, contains a number of other problems or sub-problems, weaving a true network of problems. Interrelationships even shape what could be classified as a system of problems.

However, highlighting the need for a scientific approach, the following is an outline of what could be the main problems of our administration. In order to reduce the degree of generality, we prefer to describe them with two approaches: one referring to global problems at the national level and a particular one related to the Provincial Public Administration. The growth by aggregation of the Public Administration in Ecuador has given rise to a complex structure, impossible to classify due to the lack of conceptual, organic and functional delimitation, producing a true atomization of the Public Sector. This is easy to see at practically all levels of government. 
The legal-administrative figures of autonomy, semi-autonomous affiliation, private entity with social or public purpose, applied to different State agencies have not been clearly defined, but they have been used indiscriminately. This situation has made it especially difficult to apply the criteria of universality and balance in development planning and in the administration of resources. The Public Administration has gradually added to its traditional purposes an innumerable number of new purposes, which, although they are intermediate, by their nature, have complicated their organization and operation, without, on the other hand, having acted on it systematically to adapt it to these variations.

Today's Administration has different purposes, which can be very complex; It is no longer made up of sets of activities, but rather sets of systems; it is governed by an environment not only of a national nature but also an international one; the resources it handles are voluminous and delicate; the number of its servers is appreciable; it has incorporated new and sophisticated technologies; the regulations that govern it are countless and intricate; in short, it is a system whose behavior is unpredictable, but which must respond every day to greater demands; all of which proves the advisability of examining new ways of treating it.

The formalism is expressed in the emphasis on treating public institutions, through the application of generalized criteria of a massive, simplistic and reductionist nature, without recognizing that each State organism generates and maintains its own and therefore particular system of values, it is that is, a culture of its own to whose nature structures, plans, manuals, procedures and ultimately all formal aspects of the organization are conditioned in practice. Ultimately it would be useless to modify the organization charts if the organizational culture is not transformed.

On the other hand, formalism is explained by the tendency to consider that the mere creation of organizations solves national problems. This vision of the administrative phenomenon has originated a state of rigidity in both structures and behaviors. An old thought warns that organizations must respond to the historical age in which they live. It would seem that in the case of the Public Sector, it has been intended that its structures become timeless, without considering the indispensable innovation and adaptation that not only growth and the new demands that it must meet, for a highly dynamic and sensitive society, but also demand. Even more, the problematic and critical environment within which it operates.

Referring to private organizations, the authors Toffler and Vázquez (1986) argue "when such an overwhelming wave of change crashes against society and the economy, traditional managers, accustomed to operating in calm waters, go head overboard, as is already typical. Now the habits of a lifetime-those same habits that helped them to succeed-are counterproductive and the same is applicable to organizations. Precisely the products, procedures and organizational forms that helped them in the past to achieve the success, they tend to show now their ineffectiveness. In truth, the first precept for survival is very clear: there is nothing as dangerous as yesterday's success." 
Referring to public organization, it could be affirmed that the current historical age no longer resists the orthodox uses of authority, the eminently pyramidal forms of administrative structures, individualized work, the exaggerated specialization of functions. Rather than trying to detail the last item, the org chart, job manual, job description, procedures, etc. Modern advances in management emphasize the usefulness of organizational ambiguity. A structure tied to a fully detailed organizational chart tends to develop significant rigidity phenomena (Kliksberg, 1987).

In these terms, the organizational structures of a good part of the Public Sector correspond almost exactly to its time of creation. The variations that have occurred in them have been basically to expand them, not to make them more dynamic, so surely the current capacity of most State institutions may have been enough to function adequately in the 1940s or 1950s, but never, in today's age. In this, innovative criteria are required that make it possible to manage scarcity with greater rationality, for which, among other demands, new models and other skills are needed as a result of a new thinking that, rather than increasing, should be strategic. One should not seek the improvement of what already exists, which is often incorrect or inconvenient, but rather think in new ways or in different schemes, eliminating what, due to routine, has become indispensable, but ineffective.

\section{Conclusion}

If we make a comparison between the past and present, public administration was not conceived as a science, much less talked about the public, the states work daily depending on the urgent activities that were necessary to execute them, ignoring that this theory is the foundation for the application of an order within the organization. It can be established that the study of public administration is a very broad and dynamic fact to understand, not only because it is analyzed from the point of view of the social sciences, where the purpose is the fulfillment of collective needs, as well as the study of the norms that must be applied for the correct development of the state apparatus studied as an activity.

The State can be defined as a system made up of different parts that in the end generate results that can be positive or negative so that the coordination carried out by organizations through their personnel to comply with public policies will be reflected in the quality of life of society. There is a direct relationship between the administration and the state since an administration without a state can be considered, however, a state cannot exist without an administration; It is here that the origin of public administration has long been, as well as its legality and justification, in the permanence of time and the development of society.

\section{Conflicts of Interest}

The authors declare no conflicts of interest regarding the publication of this paper. 


\section{References}

Alonso, J. A. G., Perez, Y. M., \& Hidalgo, D. B. (2016). Empleo de indicadores bibliométricos para la realización de un estado del arte. Un enfoque práctico. Revista Publicando, 3, 81-97.

Balcazar, H., Rosenthal, E. L., Brownstein, J. N., Rush, C. H., Matos, S., \& Hernandez, L. (2011). Community Health Workers Can Be a Public Health Force for Change in the United States: Three Actions for a New Paradigm. American Journal of Public Health, 101, 2199-2203. https://doi.org/10.2105/AJPH.2011.300386

Bapuji, M. (1989). Paradigms of Public Administration: An assessment. The Indian Journal of Political Science, 50, 389-401.

Basheka, B. C. (2012). The Paradigms of Public Administration Re-Examined: A Reflection. Journal of Public Administration, 47, 25-67.

Bravo Hidalgo, D., \& León González, J. L. (2018). Divulgación de la investigación científica en el Siglo XXI. Revista Universidad y Sociedad, 10, 88-97.

Desmarchelier, B., Djellal, F., \& Gallouj, F. (2019). Innovation in Public Services in the Light of Public Administration Paradigms and Service Innovation Perspectives. In Proceedings of 24th International RESER Conference: Services and the future of the workforce (p. 2).

Estrada, F. M. (2011). Gobernanza y calidad en la gestión pública. Estudios gerenciales, 27, 205-223. https://doi.org/10.1016/S0123-5923(11)70176-0

Gerring, J., \& Thacker, S. C. (2004). Political Institutions and Corruption: The Role of Unitarism and Parliamentarism. British Journal of Political Science, 34, 295-330. https://doi.org/10.1017/S0007123404000067

Gomes, J., \& Domingues, L. (2014). The Portuguese Government Cloud Services, Deployment and Management Framework. In Proceedings of the Atas da Conferência da Associação Portuguesa de Sistemas de Informação (p. 3 ).

Guevara Carrillo, J. L. (2006). Motivación de las decisiones de la administración pública en la legislación ecuatoriana. Universidad Andina Simón Bolívar, Sede Ecuador.

Henry, N. (1975). Paradigms of Public Administration. Public Administration Review, 35, 378-386. https://doi.org/10.2307/974540

Henry, N. (2015). Public Administration and Public Affairs. Routledge. https://doi.org/10.4324/9781315663067

Hood, C. (1995). The "New Public Management" in the 1980s: Variations on a Theme. Accounting Organizations and Society, 20, 93-109. https://doi.org/10.1016/0361-3682(93)E0001-W

Jianu, E., Ciobanu, N., \& Cioboata, R. (2013). Techniques and Methods to Improve the Communication Channels in Modern Public Administration. Procedia-Social and Behavioral Sciences, 92, 174-179. https://doi.org/10.1016/j.sbspro.2013.08.655

Kisil, M. (1982). Public Administration in the Health Sector for the Decade 1980-1990. II. Comparative Examination of 3 General Paradigms. Bol Ofic Sanit Panamer, 92, 328-336.

Kliksberg, B. (1987). Transformación del Estado en América Latina: Del Estado heredero al Estado necesario. Paper Presented at the Los procesos de transformación en la administración pública iberoamericana: Limitaciones y desafios.

Lovrich Jr., N. P. (1985). Contending Paradigms in Public Administration: A Sign of Crisis or Intellectual Vitality? Administration \& Society, 17, 307-330.

https://doi.org/10.1177/009539978501700304

Oliart, F. A. (1958). Administración pública, de Simón Smithburg y Thompson. Docu- 
mentación Administrativa.

Ossorio, A. (2007). La gestión pública por objetivos y resultados. Una visión sistémica. Jefatura de Gabinete de Ministros.

Oszlak, O. (1999). Quemar las naves (o cómo lograr reformas estatales irreversibles). Iv Congreso Internacional del clad.

Ricoy, C. J. (2005). La teoría del crecimiento económico de Adam Smith. Economía y desarrollo, 138, 11-47.

Salarzehi, H., \& Ebrahimpour, H. (2012). Paradigms of Public Administration: From Traditional Public Administration to Good Governance. Journal of Public Administration, 4, 34-62.

Smith, A. (1776). La riqueza de las naciones. Instituto Universitario Nacional de Derechos Humanos "Madres de Plaza Mayo" (IUNMA).

Stoker, G. (2006). Public Value Management. The American Review of Public Administration, 36, 41-57. https://doi.org/10.1177/0275074005282583

Terán, J. C. P. (2018). Análisis de la evolución de la administración pública y su aplicación en la UPEC. Visión Empresarial, No. 8, 50-60. https://doi.org/10.32645/13906852.775

Toffler, A., \& Vázquez, M. (1986). La empresa Flexible. Hombre y Sociedad.

Valle Franco, A. (2020). La Administración pública: Un enfoque desde la teoría del Estado y los derechos humanos (p. 198). Instituto de Altos Estudios Nacionales.

White, L. D. (1964). Introducción al estudio de la administración pública.

Wood, B. D., \& Waterman, R. W. (1991). The Dynamics of Political Control of the Bureaucracy. American Political Science Review, 85, 801-828. https://doi.org/10.2307/1963851

Zamora-Boza, C., Arrobo-Cedeño, N., \& Cornejo-Marcos, G. (2018). El Gobierno Electrónico en Ecuador: La innovación en la administración pública. Revista Espacios, 39, 8. 